\title{
Metacognitive Awareness and Critical Thinking Abilities of Pre-service EFL Teachers
}

\author{
Dilek Çakıc1 ${ }^{1}$ \\ ${ }^{1}$ Faculty of Education, Ondokuz Mayıs University, Samsun, Turkey \\ Correspondence: Dilek Çakıcı, Ondokuz Mayıs Üniversitesi Kurupelit Kampüsü Eğitim Fakültesi A Blok, \\ Samsun, Turkey. Tel: 90-362-312-1919.
}

Received: May 10, 2018

Accepted: June 3, 2018 Online Published: July 20, 2018

doi:10.5539/jel.v7n5p116

URL: https://doi.org/10.5539/jel.v7n5p116

\begin{abstract}
The primary aim of current study was to investigate the possible relationship between Metacognitive Awareness (MA) and Critical Thinking Skills (CTS) in a foreign language learning context. In addition, this research aimed to probe the effect of gender and years of pre-service English language teachers on the relation between metacognitive awareness and critical thinking abilities. 218 pre-service EFL (English as a Foreign Language) teachers participated in the study. Metacognitive Awareness Inventory and Critical Thinking Questionnaire were employed to gather necessary data. Obtained results confirmed that there existed a highly significant positive correlation between MA and CTS. Besides, the results indicated that there was a strong relation between the years of pre-service EFL teachers and their MA and CTS. Seniors were found to be more metacognitively aware and critical thinkers than their counterparts. Conversely, it was revealed that there was no gender effect on both MA and CTS. Finally, certain suggestions were set for tertiary institutions to develop metacognition and critical thinking skills in foreign language classroom settings.
\end{abstract}

Keywords: critical thinking, higher order skills, metacognition, metacognitive awareness

\section{Introduction}

\subsection{Introduce the Problem}

There has been necessarily a growing awareness to think about thinking in the highly demanding and challenging educational realm recently. In conjunction with the increasing popularity of cognitive psychology, there has been a quite buzz around the terms metacognition and critical thinking. Thus, most researchers heralded new views on the substantial and probable relationship between metacognition and critical thinking. Over the years a considerable amount of research has been carried out with the aim of identifying two constructs assuming an increasingly central place in cognitive development research. In fact, metacognition has stimulated a flood of recent research and publications in language learning. With this background, the bulk of the research on relation between MA and CT, however, ultimately offers researchers a prescription for encouraging students to enhance their ways of knowing or their thinking skills.

Despite the growth in the number of research studies dealing with educational psychology, there remains a great debate and confusion as to what metacognition is. In general meaning, metacognition refers to individuals' awareness of and control over the way they process information (Meltzer, Pollica, \& Barzillai, 2007). As one of the intriguing phenomena in the field of language learning, the term metacognition was firstly introduced by Flavell (1976). Metacognition is “one's knowledge concerning one's own cognitive processes and outcomes or anything related to them" (Flavell, 1976, p. 232). In a later study, Flavell (1979) conceptualized metacognition as "knowledge and cognition about cognitive phenomena" and "thinking about thinking" (Flavell, 1979: 906). Metacognition is the awareness (Kuhn \& Dean, 2004) which is reportable and conscious about the cognitive aspects (Jacobs \& Paris, 1987) of higher order thinking which involves active control over the cognitive processes engaged in learning (Livingston, 1997). It is concerned with guiding the learning process itself (Harris, 2003 ) and the ability to reflect on, understand, and control one's learning (Schraw \& Dennison, 1994: 460). In literature, metacognition is stated to have a variety of aspects. Accordingly, Schraw (2001, p. 3) offered two main aspects of metacogniton as metacognitive knowledge and metacognitive regulation. Metacognitive knowledge is "multidimensional, domain- general in nature and teachable". As for metacognitive knowledge (knowledge of cognition), it refers to "what individuals know about their own cognition in general", and includes three various 
metacogntive awareness: declarative knowledge refers to knowing "about" things. Procedural knowledge is to know "how" to do things. Conditional knowledge entails knowing the "why" and "when" aspects of cognition that affects learning such as why strategies are effective, when they should be employed and when they are appropriate (Schraw \& Moshman, 1995, p. 352). Nonetheless, metacognitive regulation refers to metacognitive actions or activities that help learners to control their learning. It is suggested three main regulatory skills: planning, monitoring, and evaluation (Schraw, 1998) though it is also suggested to have subdimensions such as planning, monitoring, information management, debugging, and evaluation (Jacobs \& Paris, 1987). Indeed, planning includes "the selection of appropriate strategies and the allocation of resources that affects performance" (Schraw, 1998, p. 115). Hence, monitoring entails "one's on-line awareness of comprehension and task performance". And evaluating involves "appraising the products and regulatory processes of one's learning" (Schraw, 1998, p. 115). It is highly emphasized that knowledge of cognition and regulation of cognition are related to one another (Schraw, 1998). Conversely, Flavell's metacognition model is comprised of the following components: metacognitive knowledge, metacognitive experiences, goals/tasks, and actions/strategies. Metacognitive knowledge refers to the person's knowledge or perceptions about three variables: person, task, and strategy. The person is any knowledge or awareness about how one learns and processes their cognitive activities. As for task variable, it represents knowledge about the nature of the task. The third variable includes the strategies needed for attaining the goals. The second category, metacognitive experiences, cognitive or affective experiences regarding intellectual functions, success, uncertainty, or satisfaction about things is included in this category. As for goals (or tasks), they refer to the aims of any cognitive projects. The last category refers to actions (or strategies) are employed by learners to attain their metacognitive objectives (Iwai, 2011). Metacognition or metacognitive awareness entails thinking of one's own thinking process and also organizing that process by arranging necessary strategies to employ, after observing his own performance by checking the effectiveness of the strategies, and lastly by judging the strategy implementation on a given task (Chamot, 1998). A major claim of metacognitive research is that MA enables to reflect on one's own thinking, develop and use practical problem-solving skills to resolve learning difficulties (Joseph, 2010). Moreover, metacognitive awareness allows individuals to plan, manage, and monitor their own thinking in a way that directly effects performance and also gains the ability to master information and employ necessary strategies to solve problems more easily (Schraw \& Dennison, 1994). In a sense, high metacognitive users are likely to plan for effective learning, organize when to use specific strategies, know how to check the use of strategies, learn how to integrate different strategies, and evaluate the effectiveness of strategy use (Anderson, 2015).

The cultivation of the ability to think critically deserves to be investigated as one of ultimate missions of education in the 21 st century. Within the changing landscape of learning, the critical thinking as a rapidly growing concept in education is believed to be the most salient skill and highly needed to be acquired. The information flow of today's global learning views thinking critically as "judging in a reflective way what to do or what to believe" (Facione, 2000, p. 61). It is extremely noticeable that as a metacognitive process, the study of critical thinking has blossomed in the psychological framework of educational literature. Conceptually, critical thinking refers to "inquisitiveness, open-mindedness, systematicity, analyticity, truth-seeking, critical thinking self-confidence, and maturity" (Facione, 2007, p. 10). In this regard, critical thinking, by definition, is a complex process that entails the use of higher levels of cognitive skills in the information process (Choy \& Cheah, 2009). In that process, it is needed to reflect on what is known and how that knowledge is justified, as well (Kuhn, 1999: 23). Critical thinking is attributed to have crucial characteristics of higher order thinking skills. Once again, Facione (1990, p. 3) proposes that critical thinking is "purposeful, self-regulatory judgment which results in interpretation, analysis, evaluation, and inference, as well as explanation of the evidential, conceptual, methodological, criteriological, or conceptual considerations upon which that judgment is based". From this perspective, critical thinking as the intentional application of rational and higher order thinking skills, such as analysis of arguments, problem recognition and problem solving (Angelo, 1995), making inferences using inductive or deductive reasoning, judging or evaluating (Lai, 2011). In the words of Halpern (1998, p. 450), critical thinking is "the use of cognitive skills or strategies that increase the probability of a desirable outcome". Pascarella and Terenzini (1991, p. 118) theorized that "...critical thinking involves the individual's ability to: identify central issues and assumptions in an argument, recognize important relationships, make correct inferences from data, deduce conclusions from information or data provided, interpret whether conclusions are warranted on the basis of the data given, and evaluate evidence or authority. As an influential factor in the development of critical thinking abilities, metacognition requires the deployment of higher order thinking skills. Similarly, critical thinking is a higher order thinking activity that requires a set of cognitive skills (Burden \& Byrd, 1994) as follows the ability to define and focus on a problem to understand and judge the validity and consistency of the hypothesis and information (Kennedy, Fisher, \& Enis, 1991). Appearently, most educators 
today favor the view that critical thinking is a higher-order process. It is also questioned how it is associated with other mental processes based on these premises above.

The present research hypothesizes that critical thinking is the indispensable part for the construction of metacognition (Flavell, 1979; Kuhn, 1999) because it involves "awareness of one's own thinking" and reflection on the thinking of self and others as an object of cognition. As for metacognition, it is defined in similar terms as awareness and management of one's own thought (Kuhn and Dean, 2004). In fact, it has been perceived that critical thinking involves a higher level of metacognitive ability or entails the employment of higher level of cognitive skills such as metacognition in information process (Choy \& Cheah, 2009). Further to this, critical thinking is likely to be developed through metacognition (Schoen, 1983; Magno, 2010). A massive body of research literature has proven the remarkable relation between metacognition and critical thinking (Schoen, 1983; Halpern, 1998; Choy \& Cheah, 2009; Coutinho, Weimer-Hasting, Skowronski, \& Britt, 2005; Kuhn \& Dean, 2004; Magno, 2010). CTS and metacognition are strongly linked to develop active participation of all levels of knowledge. CTS entail the processes of actively questioning and analyzing information to gain knowledge. As for metacognition, it necessitates being aware of what you know and do not know at various levels of cognition, and strategies to control learning process. How and why questions make students to realize and understand the material. They easily and efficiently make decisions for what learning strategies they will employ to answer higher level questions (Lockwood, 2003). In other words, metacognition helps learners make adjustments in plans and strategies accordingly during the critical thinking process (Corliss, 2005). In this regard, metacognition is so significant for a person's development of critical thinking since it may provide an incentive to develop his/her critical thinking. Clearly, metacognition and critical thinking lead to high levels of cognition or thinking skills like reasoning, long term remembering, and analyzing provide greater success in idea formation, decision making and problem solving (Lockwood, 2003). Meanwhile, critical thinking is the ability of an individual to think critically regarding his own thinking known as metacognition (Paul, 2004). Based on the previous research, it is maintained that critical thinking is positively correlated with metacognition; "improvements in one are paralled by improvements in other" (Facione, 1992, p. 18). Halpern (1998) suggested a four-part model of instruction for critical thinking. The last element of critical thinking instruction is metacognitive monitoring which refers to how the student uses this knowledge to direct and improve the thinking and his/her learning process. When the students are engaged in critical thinking, they need to employ particular metacognitive skills as follows: monitoring their thinking process, checking that progress is being made toward a suitable goal, ensuring accuracy, and making decisions about the use of time and mental effort. Similarly, Kuhn and Dean (2004, p. 270) represent that critical thinking entails awareness of one's own thinking and reflection on the thinking of self and others as an object of cognition. Thus, metacognition is identified as awareness and management of one's own thought. Schoen (1983, p. 87) posits the relation between critical thinking and metacognition as follows "a successful pedagogy aiming the enhancement of thinking would incorporate ideas about the way in which learners organize knowledge and internally represent it and the way these representations change and resist change when new information is encountered". In the research literature, critical thinking that has received relatively little attention from language educational philosophers. Similarly, there has been limited empirical research that directly investigates the employment metacognitive and critical thinking skills in foreign language context. Therefore, based on the theoretical assumptions mentioned elaborately above, it is expected that the critical thinking skills would be associated positively with metacognition.

\subsection{Importance of the Problem}

Having a glance on the related literature, it is realized that despite a plethora of research on the relation between critical thinking and metacognition in other disciplines, there is a comparative dearth of study in Turkish EFL context at tertiary education. For this purpose, the researcher endeavors to explore whether there was any significant relationship between metacognitive awareness and critical thinking abilities of pre-service teachers majoring in ELT department. The present study mainly sought to probe whether a significant relationship exists between MA and CTS of pre-service EFL teachers with regard to gender and the years of education. For this purpose the following research questions were posed:

1) Is there a correlation between pre-service teachers' MA and CTS?

2) Is there a significant relationship between pre-service teachers' gender and their MA?

3) Is there a difference between student teachers' years of education and their MA?

4) Is there gender effect on pre-service teachers' CTS?

5) Is there a significant relation between pre-service teachers' years of education and their CTS? 


\section{Method}

The current research was a correlational study. Samples were chosen according to random sampling clusters. This study adopted a descriptive kind of general survey research design with a quantitative method. The descriptive approach aims to determine current condition of research interest. Survey models are the research approaches that aim to define past or existing situations.

\subsection{Participants}

The participants of this study consisted of Turkish University students enrolling in ELT bachelor program at Ondokuz Mayıs University in Samsun. A total of 218 Turkish EFL undergraduate students (165 females, 53 males) in Ondokuz Mayıs University at ELT Department constituted the the sample of the study. Of the 218 students, 35 were first-year, 41 were the second-year students, 66 were the third-year students, and 76 were the fourth-year students.

\subsection{Data Collection and Analysis}

To obtain quantitative data for the present research, two significant instruments were used: Critical Thinking Questionnaire (CTQ) and Metacognitive Awareness Inventory (MAI). CTQ developed by Honey (2000) aims at assessing the three basic skills of comprehension, analysis, and evaluation of the EFL learners. The CTQ which intends to explore what a person might or might not do when thinking critically about a subject is a 5-point Likert-type questionnaire with 30 items ranging from never to always. The possible scores were ranged of 30 to 150. The reliability of the critical thinking questionnaire for the present study was estimated to be .89 which indicated a reasonable degree of reliability. The MAI developed by Schraw and Dennison included 52 statements to measure the adults' metacognitive awareness as a five-point likert scale from strongy agree to strongly disagree (Schraw and Dennison, 1994). Cronbach's Alpha for the MAI used in this study was reported .93 which manifested a satisfactory reliability. The internal consistencies of the MAI, was found .95 for the entire scale. The pearson correlation analysis was performed to test the relationship between MA and CTS. In order to determine gender effect on the scores of MA and CTS, an independent t-test was conducted. In addition, ANOVA test was employed to examine the relations between the years of students and MA, also and CTS.

\section{Results}

The main purpose of the present study was to examine the relation between metacognitive awareness and critical thinking abilities of pre-service English teachers. Furthermore, this research endeavored to explore the relation between MA and CTS in terms of gender and the years of pre-service teachers. In the first research question, the researcher attempts to test whether there is a relationship between Turkish EFL students' metacognitive awareness and their critical thinking abilities. To this end, Pearson correlational procedure was conducted. The results from Pearson product moment correlation coefficients between MA scores and CTS scores are presented in Table 1.

Table 1. The results of Pearson correlation for metacognitive awareness and critical thinking skills

\begin{tabular}{llll}
\hline & & MA & CTS \\
\hline \multirow{3}{*}{ MA } & Pearson Correlation & 1 & $.731(* *)$ \\
& Sig. (2-tailed) & & .000 \\
& $\mathrm{~N}$ & 218 & 218 \\
\hline \multirow{3}{*}{ CTS } & Pearson Correlation & $.731\left(^{* *}\right)$ & 1 \\
& Sig. (2-tailed) & .000 & \\
& $\mathrm{~N}$ & 218 & 218 \\
\hline
\end{tabular}

** Correlation is significant at the 0.01 level (2-tailed).

The findings in Table 1 represent that there is a highly strong and significant positive correlation between prospective teachers' metacognitve awareness and their critical thinking skills $(r=.73, p=.000)$. A positive ratio observed between MA and CTS suggests that MA and CTS are closely related constructs. That means that EFL teachers who are more critical thinkers are also metacogntively aware as well.

The second research question aims to determine whether there exists a significant difference between the scores of metacognitive awareness of female and those of male pre-service English teachers. The related findings are displayed in Table 2. 
Table 2. Independent t-test results for gender and metacognitive awareness

\begin{tabular}{llllllll}
\hline & Gender & $\mathrm{N}$ & Mean & SD & df & t & $\mathrm{p}$ \\
\hline Metacognitive & Females & 165 & 1.92 & 24.56 & 216 & 1.20 & .233 \\
Awareness & Males & 53 & 1.87 & 23.15 & & & \\
\hline
\end{tabular}

${ }^{*} \mathrm{p}>0.05$.

As it is viewed in Table 2, the mean of test anxiety scores for females $(\mathrm{M}=1.92)$ is slighlty greater than that of the males $(\mathrm{M}=1.87)$. The results of the independent $\mathrm{t}$-test show that there is no difference between female and male pre-service teachers' metacognitive awareness.

The third research question examines whether or not there is any significant relationship between the years of pre-service teachers and their MA. In Table 3, ANOVA results are delineated.

Table 3. ANOVA results for the years of students and metacognitive awareness

\begin{tabular}{lllllll}
\hline Year & $\mathrm{N}$ & Mean & SD & df & F & p \\
\hline 1 & 35 & 1.84 & 26.05 & 3 & 8.09 & $.000^{*}$ \\
2 & 41 & 1.88 & 24.24 & 214 & & \\
3 & 66 & 1.84 & 20.62 & & & \\
4 & 76 & 2.00 & 23.49 & & & \\
\hline
\end{tabular}

$* \mathrm{p}>0.05$.

As illustrated, there is a significant relation between the years of prospective teachers and their MA. Based on the obtained results, it is observed that metacognitive awareness differs according to the years of preservice teachers. In other words, there exists a significant relation between freshmen and seniors $\left(\mathrm{MD}=15.92, \mathrm{p}=.005^{*}\right)$, between sophomores and seniors $\left(\mathrm{MD}=12.50, \mathrm{p}=.030^{*}\right)$, between juniors and seniors $\left(\mathrm{MD}=16.67, \mathrm{p}=.000^{*}\right)$. This result may be interpreted as the seniors are highly aware of thinking about thinking. Namely, this finding suggests that years of propspective EFLteachers in the study is reasonably associated with their MA.

The present study investigates the role of gender on critical thinking skill. The findings related with the effect of gender on critical thinking abilities are presented in Table 4.

Table 4. Independent t-test results for gender and critical thinking abilities

\begin{tabular}{llllllll}
\hline & Gender & $\mathrm{N}$ & Mean & SD & df & t & p \\
\hline Critical & Females & 165 & 1.08 & 13.33 & 216 & .498 & .619 \\
$\begin{array}{l}\text { Thinking } \\
\text { Skills }\end{array}$ & Males & 53 & 1.07 & 13.20 & & & \\
\hline
\end{tabular}

${ }^{*} \mathrm{p}>0.05$,

Based on the research findings in Table 4, it is detected that there is no difference between female and male pre-service English teachers' critical thinking skills. This finding implies that the prospective teachers' critical thinking abilities do not differ according to their gender.

Finally, it is intended find out if there is any significant relation between the years of pre-service teachers' and their CTS. To this end, ANOVA is performed. Table 5 displays related findings to that research question.

Table 5. ANOVA results for the years of students and critical thinking skills.

\begin{tabular}{lllllll}
\hline Year & $\mathrm{N}$ & Mean & SD & df & F & p \\
\hline 1 & 35 & 1.09 & 14.29 & 3 & 8.09 & $.000^{*}$ \\
2 & 41 & 1.00 & 13.41 & 214 & & \\
3 & 66 & 1.06 & 11.90 & & & \\
4 & 76 & 1.12 & 12.10 & & & \\
\hline
\end{tabular}

$* \mathrm{p}>0.05$. 
According to the findings, it is viewed that the year of pre-service EFL teachers is highly associated with their CTS. As a matter of fact, being freshmen, sophomores, juniors and seniors have a great effect on their critical thinking abilities. The results delineate that there is a significant connection between freshmen and sophomores $\left(\mathrm{p}=.016^{*}\right)$, between sophomores and seniors $\left(\mathrm{p}=.000^{*}\right)$, between juniors and seniors $\left(\mathrm{p}=.046^{*}\right)$. Apparently, mean and $p$ value denote that CTS differ with regard to the year of participants of current research.

\section{Discussion}

This study was conducted to delve into the correlation among pre-service English teachers' metacognitive awareness (MA) and their critical thinking skills (CTS). In additon, it was aimed to investigate the effects of gender and the years of students on both MA and CTS. Based on the results of the study, it was reported that there was a highly significant and strong positive correlation between MA and CTS of EFL prospective teachers. This finding revealed that the more metacognitive awareness increases in pre-service teachers, the more critical thinking develops, as well. Further to this, MA and CTS are closely related constructs and they are not independent of each other. This finding of current research is consistent with previous studies (Magno, 2009; Magno, 2010; Semerci \& Elald1, 2014; Halpern, 1993; Choy \& Cheah, 2009; Sadeghi, Hassani, \& Rahmatkhah, 2014; Pithers \& Soden, 2000; Kuhn \& Dean, 2004; Lee, 2009; Ku \& Ho, 2010; Daud \& Hafsari, 2015; Mall-Amiri \& Ahmadi, 2014; Halpern 1998; Nickerson 1994; Anderson, 2002; Flavel, 1976; Pintrich, Smith, Garcia, \& Mc Keachie, 1993; Schoen, 1983; Kaur, 2017; Nemat \& Erfani, 2014). This finding represented that metacognitive skills governs and directs critical thinking abilities. Learners are apt to employ metacognition in order to think critically. Obviously, critical thinking may occur when learners engage in essential metacognitive skills. Thus, it is plausible explanation that metacognition has a crucial pathway to CTS. This implies that metacognition entails the skills to use knowledge to control and develop higher order thinking abilities. There is a growing consensus that the improvement of the students' CTS is facilitated through metacognition. Based on the previous research, it is maintained that critical thinking is positively correlated with metacognition; "improvements in one are paralled by improvements in other" (Facione, 1992, p. 18). The link between metacognition and critical thinking is defined as a meta-theoretical framework because an executing strategy is required such as metacognition to attain an executive skill (Magno, 2010). While engaging in critical thinking, students need to undergo certain metacognitive skills such as monitor their thinking process, checking that progress toward a relevant goal, ensuring accuracy, and making decisions regarding the use of time and mental effort (Halpern, 1998). Ku and Ho (2010) clarified that good critical thinkers experienced specifically higher level metacognitive activities, On the other hand, a little research findings contended no correlation between MA and CTS (Niemivirta, 1997; Kamid, 2013).

According to the result of current research, there was no effect of gender on the students' MA. This finding of research suggested that both males and females employ their metacognitive skills. In other words, MA was not dependent on gender in the present study. This finding is compatible with many similar studies examining the effects of gender on MA. Özsoy and Günindi (2011) explored the prospective preschool teachers' metacognitive awareness and its relation in terms of gender, grade, and the types of high school they have graduated. The results argued that there was no significant difference between females and males in their MA. Kamid (2013) stated that there was not any difference in metacognition ability between male and female students when completing a task. Moreover, a wealth of research related to the effect of gender on metacognitive skills reached the similar conclusion that there was not any difference in metacognitive skills between male and female students (Niemivirta, 1997; Carr \& Jessup, 1997; Bidjerano, 2005; Memnun \& Akkaya, 2009; Akman \& Alagöz, 2018; Hashempour, Ghonsooly, \& Ghanizadeh, 2015; Kaur, 2017; Jaleel \& Premachandran, 2016; Walberg, Harnisch, \& Tsai, 1986; Friedman, 1989; Özsoy \& Günindi, 2011; Sczesny \& Kühnen, 2004; Benson, 2001; Vianty, 2007; Siswati \& Corebima, 2017; Chisholm, 1999; Zülkiply, Kabid, \& Ghani, 2008; Logan \& Johnston, 2009). This finding of the research may be interpreted as gender is not a distinctive feature to be metacognitively aware. There might be certain other components or variables playing significant roles for enhancement of MA. In the case of gender differences, a considerable amount of research has observed that MA and gender are significantly correlated. Namely, the finding of this research related gender effect is in contrast with the results of the research conducted by Arrastia, Zayed and Elnagar, 2016; Byrne, 1993; Ogus and Ataseven, 2016; Liliana and Lavinia, 2011; Sadeghi, Hassani and Rahmatkhah, 2014; Sheorey and Monktari, 2001; Miller, 2000; Rozendal, Minnaert and Boekaert, 2001; Misu and Masi, 2017; Renninger, Hidi and Krapp, 1992; Sabna and Hameed, 2016; Eccles, Wigfield, Harold and Blumenfeld, 1993.

As for the relation between MA and the years of prospectice teachers, the results implied that MA differs according to the years of pre-service EFL teachers. MA scores of seniors were higher than those of freshmen, sophomores, and juniors. This result may be interpreted as the seniors have learned to manage and monitor their 
cognition, and their cognitive skills. Additionally, they play active role in their learning process to regulate, manage, and direct, and to judge what they have learned in time. This finding of study is in harmony with almost all relevant previous studies in literature (Memnun \& Akkaya, 2009). Siswati and Corebima (2017) found a significance difference in metacognitive skills between junior high school students and senior high school students. The mean of metacognitive scores of senior high school students was relatively higher than that of the junior counterparts. The scores of MA increase from lower grades to upper grades. Possible explanation for this finding is that the 4th year students are apt to have more knowledge of metacognition about their skills, how to manage and implement their learning procedures, analyse, and evaluate their performances. Namely, senior students are likely to have higher levels of metacognitive awareness in comparison with first, second, and third year counterparts. Another acceptable explanation for this finding is that the students' metacognition with regard to their years at university tends to develop over time. It was interpreted that higher education level may correspond to higher metacognitive awareness. The fourth-year students seemed to be more educated and experienced regarding knowledge about cognition and regulation of cognition. They are supposed to deploy metacognitive skills more strategically, more frequently and appropriately. Building on the finding of the current study, it is contended that upper-class of EFL pre-service teachers have reported greater MA compared to their younger counterparts. In fact, this finding of research supported by the claim proposed regarding developmental nature of metacognitive awareness. A bulk of research asserts that metacognitive growth is an ongoing developmental procedure. Metacognitive ability improved significantly with age during adolescence, was highest in late adolescence and plateaued going into adulthood in adolescence (Weil, Fleming, Dumontheil, Kilford, Weil, Rees, Raymond, Dolan, \& Blakemore, 2013). Adolescents resume the metacognitive growth through their university education. Evidence as to the years of students and metacognitive skills relation in language literature is scarce. Younger children show simple knowledge of metacognitive and employ metamemory strategies but as they get older, they learn to use cognitive resources more strategically and improve more complex ways of using and monitoring their strategies (Holland \& Kurtz-Costes, 1997). From this perspective, the students from different grades differed in the awareness of the metacognitive skills. Kuhn (2000, p. 178) maintains that metacognition should be conceptualized in a developmental framework. During its extended developmental course, metacognition becomes more explicit, powerful, and effective, as it comes to operate increasingly under the individual's conscious control. Similarly, Arrastia, Zayed and Elnagar (2016) probed the effect of years of students on the MA. According to results, the fourth-year students employ strategies more often as compared to first-year students in the context of reading English. On the other hand, this result of present research is not in line with previous studies (Zülkiply, Kabid, \& Ghani, 2008; Akman \& Alagöz, 2018; Özsoy, Çakıroğlu, Kuruyer, \& Özsoy, 2010; Hashempour, Ghonsooly, \& Ghanizadeh, 2015).

The current study also attempts to trace any difference between male and female prospective teachers in their CTS. According to research findings, there is no effect of gender on pre-service teachers'CTS. In other words, CTS do not differ between female and male teachers. Female pre-service EFL teachers are found similar in thinking critically to the male counterparts. This finding of the present study corroborates those of numerous studies. Mowlaie and Samarein, 2014; Osman and Githua, 2009; Afsahi and Afghari, 2017; Erdem and Genç, 2015; Chisholm, 1999; Semerci and Elald1, 2014; Şen, 2009; Salahshoor and Rafiee, 2016; Walsh and Hardy, 1999 proved that males and females were not significantly different from one another in employing CTS. Depending on this finding, it may be declared that gender is not a single factor which predicts higher level of CTS. Namely, thinking critically was not dependent on gender or critical thinking surpasses gender distinction. Thus, it is plausible to suggest that gender is not considered as a salient predictor of the development of CTS. A reason posited for this finding may be that participants are from similar educational background, proficiency level, and age. Thus, it can be hypothesized that the influence of gender was dwarfed by the collective effect of factors given (Mowlaie \& Samarein, 2014). Background knowledge is a crucial but not a sufficient component for enabling critical thought within a given subject. There exist both general- and domain-specific aspects of critical thinking (Lai, 2011). Furthermore, domain-specific knowledge is postulated to impinge on in cultivating critical abilities. Domain-specific knowledge is indispensable to critical thinking because the kinds of explanations, evaluations, and evidence that are most highly valued differ from one domain to another (Bailin, Case, Coombs, \& Daniels, 1999). According to Facione (1990), learning and deploying these skills in many contexts require domain-specific knowledge which encompasses understanding methodological principles and capacity to engage in practices that are in essence of plausible judgments in those particular contexts.

Prior research also reported inconclusive findings regarding the differences in critical thinkings between females and males. The research by Sadeghi, Hassani and Rahmatkhah, 2014; Harish, 2013; Aliakbari and Sadeghdaghighi, 2011; Mohammadi, Heidari and Niry, 2012; Wilson, 1989; Leach, 2011 Brems and Johnson, 1988 put forth that boys are better critical thinkers than girls. Conversely, Ay and Akgöl, 2008; Ocak, 
Kutlu-Kalender (2017) averred that females are better in CTS than male counterparts.

It is apparent from the data obtained that CTS of seniors are statistically higher those of counterparts. That means CTS differ with regard to the years of participants of current research. A great number of factors may be positted for this differentiation. Firstly, this interesting finding can be attributed to time. It is hypothesized that CTS develop over time (Facione, 1990), and demand a developmental progression (Kuhn, 1999). By starting from the first year, the students are offered plenty of opportunities to practice the skills in order to embed them in their learning in later years (Thomas, 2011). Thus, naturally, senior students are expected to be open-minded, self-confident, analytic (Facione, 2007), and employ reflective judgement (Facione, 2000). As, building MA among learners demands a prolonged developmental progress in nature, metacognitive skills are learned and transferred to new contexts in accordance with the specific personal factors such as age, aptitude, beliefs, and learning styles. Therefore, prior studies (Gellin, 2003; O'Hare \& McGuinness) seeking the growth of CTS at tertiary level confessed that upper class of university students had higher critical thinking scores than those of first-year counterparts. In this regard, it is plausible that critical thinking mean scores increase from years 1 to 4 as it is in the current research. Conversely, Ay and Akgöl (2008); Yang and Lin, (2004) acknowledged no relation between the engagement in CTS and years of students. Given that, there was no adequate study scrutinizing effect of educational level on EFL learners, the comparison was not made with reference to previous related research in literature. As asserted by Kasımoğlu (2013), Erdem and Genç (2015), the years of students did not predict the students'critical thinking abilities. The development of metacognitive skills is pertinent to the time frame. It is overtly urged that in each year new strategies are employed in new tasks were presented to participants with a difficultiness aligned to both their ages and proficiency level. Thus, improved metacognitive skills indicated the strength of the general metacognitive repertoire in fourth year. Another piece of evidence supporting the finding of the present study by Thomas (2011) who focused in his research on the first year student, and hoped that academics in the second and third year would build on CTS and good critical thinkers making proper decisions, solving problems, suggesting possible solutions and making judgement critically.

\section{Conclusion}

Evidence is mounting that it is of the utmost importance to provide a general insight into how language learners metacognively aware to use critical thinking skills. The lack of metacognitive awareness and poor critical thinking skills in specifically in language education context are assummed to be serious matters. The result emanated from the study overtly pointed out that metacognition and thinking crtically are positively correlated. From a practical point of view, this finding has major implications for how to help students to increase their awareness of metacognition and foster their skills of critical thinking. Firstly, metacognition and critical thinking instruction should be a central part of the language teaching practises from the very beginning. Although, there is a strong need for engaging students in critical thinking, how this is realized through educational efforts is still questionable. Critical thinking is conceptualised differently depending on the discipline according to Jones (2007). So, language teaching programmes should be designed in order to enable learners to perform possible acts of critical thinking. Since, the students are not aware of how to think logically in many tertiary institutions, it should be intended to teach how to deploy specific strategies from a repertoire of strategies to set goals and monitor and evaluate their own academic development. Virtually without exception, previous studies postulated the necessities of instruction for teaching how to think critically at the tertiary level. As pointed out by Marin and Halpern (2011), instruction of critical thought may be practised with two distinct methods: imbedded instruction (critical thinking skills are integrated into the subject matter), explicit instruction (courses are designed specifically to provide guidance in specific CTS). In other words, a variety of point of views on the teachability of the ability to think critically encourage language programme designers and language teachers should pave the way for developing language courses to be included in the curriculum. Incorporating critical thinking skills in appropriate topics in classroom instruction is recommended by language scholars. Furthermore, the research in related literature provides a robust evidence that explicit instruction would also be suggested. Lai (2011) advised the explicit instruction in critical thinking, through the use of cooperative or collaborative learning methods and constructivist approaches to teach how to transfer to new contexts. Additionally, in their research, Marin and Halpern (2011) confirmed that the students receiving explicit instruction showed much larger gains than those in the imbedded instruction group. With an effort to to promote critical thinking, metacognition should be either explicitly or implicitly addressed in langauge teaching curriculum. Depending on the research results, it is asserted that all EFL teachers should make effort how to equipped their students with these extremely important skills and to explore alternative ways to practice efficiently, to organize training programmes for all the students to make them aware regarding the use of metacognition in learning process. Therefore, it is crucial to create a metacognitive learning environment entailing the employment of skills of critical thinking in EFL classroom 
praxis. How instruction is best situated whichever approaches are chosen to create a learning context supporting the development of critical thinking through metacognition is also questionable by the language teachers. Emphasizing metacognitive strategies to foster critical thinking not only increases students' thinking skills but also prepares learners with a lifelong ability to help them productively manage new situations in our changing world (Kaur 2017). In this regard, higher education instructors should mostly be trained about how to teach learning strategies that facilitate CTS and to nurture the students' talents to be metacognitively aware.

All in all, it is highly recommended that EFL teachers at tertiary level should adopt proper methods and use a host of techniques to integrate these skills effectively in the EFL classrooms. Thus, some new pedogogical roles are assumed for language teachers. Indeed, efforts will mainly need to be made to design well organized instruction for the use of effective metacognitive strategies to encourage higher order skills. As Forrester (2008, p. 104) highlighted, in order to encourage critical thinking, the students are motivated to think, provided time to develop ideas, supported by a learning community that provides information, feedback and encouragement. It is specifically suggested that promoting metacognition begins with building an awareness among learners. Next step is to teach strategies, and to help students construct explicit knowledge about when and where to use strategies. A flexible strategy repertoire may be deployed in addition to make careful regulatory decisions that enable individuals to plan, monitor, and evaluate their learning. An interactive approach that blends direct instruction, teacher and expert student modeling, reflection on the part of students, and group activities that permit learners to share their knowledge about cognition (Schraw \& Sperling, 1994).

\section{References}

Afsahi, S. E., \& Afghari, A. (2017). The relationship between mother tongue, age, gender and critical thinking level. Journal of Applied Linguistics and Language Research, 4(1), 116-124.

Akman, Ö., \& Alagöz, B. (2018). Relation between metacognitive awareness and participation to class discussion of university students. Universal Journal of Educational Research, 6, 11-24. https://doi.org/10.13189/ujer.2018.060102

Anderson, N. J. (2002). The role of metacognitive in second language teaching and learning. Modern Language Journal, 75, 460-472. https://doi.org/10.1111/j.1540-4781.1991.tb05384.x

Anderson, N. J. (2015). Academic Reading Expectations and Challenges. In N. W. Evans, N. J. Anderson, \& W. G. Eggington (Eds.), ESL Readers and Writers In Higher Education:Understanding Challenges, Providing Support. New York: Taylor \& Francis.

Angelo, T. A. (1995). Beginning the dialogue: Thoughts on promoting critical thinking: Classroom assessment for critical thinking. Teaching of Psychology, 22(1), 6-7. https://doi.org/10.1207/s15328023top2201_1

Arrastia, M. C., Zayed. A. M., \& Elnagar, H. Z. (2016). Metacognitive awareness of reading strategies among English as a foreign language (EFL) preservice teachers: An exploration of gender and developmental differences. International Research in Higher Education, 1(2), 46-57. https://doi.org/10.5430/irhe.v1n2p46

Ay, Ş., \& Akgöl, H. (2008). Eleştirel düşünme gücü ile cnsiyet, yaş ve sinıf düzeyi. Kuramsal Eğitimbilim, l(2), 65-75. Retrieved from http://dergipark.gov.tr/akukeg/issue/29373/314325

Bailin, S., Case, R., Coombs, J. R., \& Daniels, L. B. (1999). Conceptualizing critical thinking. Journal of Curriculum Studies, 31(3), 285-302. https://doi.org/10.1080/002202799183133

Bidjerano, T. (2005). Gender differences in self-regulated learning. Paper presented at the 36th/2005 Annual Meeting of the Northeastern Educational Research Association, Kerhonkson, NY.

Burden, P. R., \& Byrd, D. M. (1994). Methods for effective teaching. Boston, MA: Allyn and Bacon, Inc.

Byrne, A. M. (1993). An investigation of the interrelationships among grade six readers' concepts of self, metacognitive awareness, gender and reading comprehension (Masters thesis). Memorial University of Newfoundland.

Carr, M., \& Jessup, D. L. (1997). Gender differences in first-grade mathematics strategy use: Social and metacognitive influences, Journal of Educational Psychology, 89(2), 318-328. https://doi.org/10.1037/0022-0663.89.2.318

Chamot, A. U. (1998). Teaching learning strategies to language students. Center for Applied Linguistics, 12, $1-28$.

Chisholm, J. M. (1999). The effects of metacognition, critical thinking, gender, and gender role identification on academic achievement in the middle years (Master thesis). Halifax: Mount Saint Vincent University. 
Choy, S. C., \& Cheah, P. K. (2009). Teacher perceptions of critical thinking among students and its influence on higher education. International Journal of Teaching and Learning in Higher Education, 20(2), 198-206. http://www.isetl.org/ijtlhe/

Corliss, S. B. (2005). The effects of reflective prompts and collaborative learning in hypermedia problem-based learning environments on problem solving and metacognitive skills (Doctoral dissertation). Austin: The University of Texas.

Coutinho, S., Wiemer-Hasting, K., Skowronski, J. J., \& Britt, M. A. (2005). Metacognition, need for cognition and use of explanations during ongoing learning and problem solving. Learning and Individual Differences, 15, 321-337. https://doi.org/10.1016/j.lindif.2005.06.001

Daud, F., \& Hafsari, I. (2015). The contribution of critical thinking skills and metacognitive awareness on students' learning: Teaching biology at senior high school. Modern Applied Science, 9(12), 143-153. https://dx.doi.org/10.5539/mas.v9n12p143

Eccles, J. S., Wigfield, A., Harold, R. D., \& Blumenfeld, P. (1993). Age and gender differences in children's self and task perceptions during elementary school. Child Development, 64(3), 830-847. https://doi.org/10.1111/j.1467-8624.1993.tb02946.x

Erdem, A. R., \& Genç, G. (2015). Lise öğrencilerinin problem çözme becerileri ile eleştirel düşünme becerileri arasındaki ilişki. Türkiye Sosyal Politika ve Çalışma Hayatı Araştırmaları Dergisi, 5(8), 32-44.

Facione, P. (2007). Critical thinking: What it is and why it counts. Millbrae, CA: The California Academic Press.

Facione, P. A. (1990). Critical thinking: A statement of expert consensus for purposes of educational assessment and instruction. Research findings and recommendations. Millbrae, CA: The California Academic Press.

Facione, P. A. (1992). Critical thinking: What it is and why it counts. Retrieved from http://insightassessment.com/t.html

Facione, P. A. (2000). The disposition toward critical thinking: Its character, measurement, and relation to critical thinking skill. Informal Logic, 20(1), 61-84. https://doi.org/10.22329/il.v20i1.2254

Flavell, H. J. (1976). Metacognitive aspects of problem solving. In L. R. Resnick (Ed.), The Nature of Intelligence. Hillsdale, NJ: Lawrence Erbaum.

Flavell, J. (1979). Metacognition and cognitive monitoring: A new area of cognitive-developmental inquiry. American Psychologist, 34, 906-911. https://doi.org/10.1037/0003-066X.34.10.906

Forrester, J. (2008). Thinking creatively; thinking critically. Asian Social Science, 4(5), 100-105. https://doi.org/10.5539/ass.v4n5p100

Friedman, L. (1989). Mathematics and gender gap: A meta-analysis of recent studies on sex differences in mathemathical tasks. Review of Educational Reseach, 59(2), 185-213.

Gellin, A. (2003). The effect of undergraduate student involvement on critical thinking: A meta-analysis of the literature 1991-2000. Journal of College Student Development, 44(6), 746-762. https://doi.org/10.1353/csd.2003.0066

Halpern, D. F. (1993). Thought and knowledge: An introduction to critical thinking. Hillsdale, NJ: Erlbaum Associates Publishers.

Halpern, D. F. (1998). Teaching for critical thinking: helping college students develop the skills and dispositions of a teaching critical thinking for transfer across domains: dispositions, skills, structure training, and metacognitive monitoring. The American Psychologist, 53, 449-455. https://doi.org/10.1037/0003-066X.53.4.449

Halpern, D. F. (2000). Psychology of critical thinking. Saint-Petersburg: Piter.

Harish, G. C. (2013). Critical thinking skills among ninth standard students in relation to gender, intelligence and study habits. International Journal of Education and Psychological Research (IJEPR), 2(3), 13-20.

Harris, V. (2003). Adapting classroom-based strategy instruction to a distance learning context. TESL Internet Journal, 7(2). Retrieved from http://www.tesl-ej.org/wordpress/issues/volume7/ej26/ej26a1/

Hashempour, M., Ghonsooly, B., Ghanizadeh, A. (2015). A study of translation students' self-regulation and metacognitive awareness in association with their gender and educational level. International Journal of Comparative Literature \& Translation Studies, 3(3), 61-68. 
Holland, J. M., \& Kurtz-Costes, B. (1997). Metamemory development. In N. Cowan \& C. Hulme (Eds.), The development of memory in childhood. East Sussex: Psychology Press.

Honey, P. (2000). Critical thinking questionnaire. Retrieved from http://www.peterhoney.com

Iwai, Y. (2011). The effects of metacognitive reading strategies: Pedagogical implications for EFL/ESL teachers. The Reading Matrix, 11(2), 150-159.

Jacobs, J. E., \& Paris, S. G. (1987). Children's metacognition about reading: Issues in definition, measurement, $\begin{array}{llll}\text { and instruction. } & \text { Educational 22(3-4), }\end{array}$ https://doi.org/10.1080/00461520.1987.9653052

Jaleel, S., \& Premachandran, P. (2016). A study on the metacognitive awareness of secondary school students. Universal Journal of Educational Research, 4(1), 165-172.

Jones, A. (2007). Multiplicities or manna from heaven? Critical thinking and the disciplinary context. Australian Journal of Education, 51(1), 84-103. https://doi.org/10.1177/000494410705100107

Joseph, N. (2010). Metacognition needed: Teaching middle and high school students to develop strategic learning skills. Preventing School Failure, 54(2), 99-103.https://doi.org/10.1080/10459880903217770

Kamid (2013). Students' metacognition in solving mathematical problems Case study on junior high school students based on gender. Edumatica, 3(1), 64-72.

Kasımoğlu, T. (2013). Evaluation of critical thinking, logical thinking and problem solving skills for teaching candidates from several variables angles (Unpublished master's thesis). Ankara: Gazi University.

Kaur, K. (2017). Influence of demographic factors on metacognition and its relationship with critical thinking of higher secondary students: Foundation for learning. International Journal for Research in Applied Science \& Engineering Technology (IJRASET), 5(7), 358-363. Available at www.ijraset.com

Kennedy, M., Fisher, M. B., \& Ennis, R. H. (1991). Critical thinking: Literature review and needed research. In L. Idol \& B. F. Jones (Eds.), Educational values and cognitive instruction: Implications for reform. Hillsdale, New Jersey: Lawrence Erlbaum \& Associates.

Ku, K. Y. L., \& Ho, I. T. (2010). Metacognitive strategies that enhance critical thinking. Metacognition and learning, 5(3), 251-267. https://doi.org/10.1007/s11409-010-9060-6

Kuhn, D. (1999). A developmental model for critical thinking. Educational Researcher, 28(2), 16-26. https://doi.org/10.3102/0013189X028002016

Kuhn, D. (2000). Metacognitive development. Current Directions in Psychological Science, 9(5), 178-181. https://doi.org/10.1111/1467-8721.00088

Kuhn, D., \& Dean, D. (2004). Metacognition: A bridge between cognitive psychology and educational practice. Theory into Practice, 43(4), 268-274. https://doi.org/10.1207/s15430421tip4304_4

Lai, E. R. (2011). Critical thinking: A literature review. Pearson Research Report.

Lee, S. T. (2009). Examining the relationships between metacognition, self-regulation and critical thinking in online socratic seminars for high school social studies students (Doctoral dissertation). Texas: The University of Texas

Liliana, C., \& Lavinia, H. (2011). Gender differences in metacognitive skills. A study of the 8th grade pupils in Romania. International Conference on Education and Educational Psychology (ICEEPSY). https://doi.org/10.1016/j.sbspro.2011.11.255

Livingston, J. A. (1997). Metacognition: An overview. Retrieved from http://gse.buffalo.edu/fas/shuell/CEP564/Metacog.htm

Lockwood, F. (2003). Metacognition and critical thinking for effective learning. Retrieved from http://members.shaw.ca/donlockwood/critical.htm

Logan, S., \& Johnston, R. S. (2009). Gender differences in reading ability and attitudes: Examining where these differences lie. Journal of Research in Reading, 32(2), 199-214. https://doi.org/10.1111/j.1467-9817.2008.01389.x

Magno, C. (2009). Investigating the effect of school ability on self-efficacy, learning approaches, and metacogntion. The Asia-Pacific Education Researcher, 18(2), 233-244. https://doi.org/10.3860/taper.v18i2.1325 
Magno, C. (2010). The role of metacognitive skills in developing critical thinking. Metacognition Learning, 5,137-156. https://doi.org/10.1007/s11409-010-9054-4

Mall-Amiri, B., \& Ahmadi, Z. (2014). The relationship between EFL learners' critical thinking, and metacognitive strategies. International Journal of Language Learning and Applied Linguistics World (IJLLALW), 5(1), 374-387.

Marina, L. M., \& Halpern, D. F. (2011). Pedagogy for developing critical thinking in adolescents: Explicit instruction produces greatest gains. Thinking Skills and Creativity, 6, 1-13. https://doi.org/10.1016/j.tsc.2010.08.002

Meltzer, L., Pollica, L. S., \& Barzillai, M. (2007). Executive function in the classroom: Embedding strategy instruction into daily teaching practices. In L. Meltzer (Ed.), Executive function in education from theory to practice.

Memnun, D. S., \& Akkaya, R. (2009). The levels of metacognitive awareness of primary teacher trainees. Procedia-Social and Behavioral Sciences, 1(1), 1919-1923. https://doi.org/10.1016/j.sbspro.2009.01.337

Miller, J. W. (2000). Exploring the source of self-regulated learning: The influence of internal and external comparisons. Journal of Instructional Pyschology, 27, 47-52.

Misu, L., \& Masi, L. (2017). Comparison of metacognition awareness of male and female students based on mathematics ability in department of mathematics education of Halu Oleo University. International Journal of Education and Research, 5(6), 43-50.

Mohammadi, E. N., Heidari, F., \& Niry, N. D. (2012). The relationship between critical thinking ability and reading strategies used by Iranian EFL learners. English Language Teaching, 5(10), 192-201. https://doi.org/10.5539/elt.v5n10p192

Mowlaie, B., \& Samarein, A. E. (2014). Investigating the relationship among gender, critical thinking and metacognitive awareness listening strategies. Journal of Language and Translation, 1(7), 3-33.

Nemat-Tabrizi, A. R., \& Erfani, L. (2014). The relationship between critical thinking and cognitive and metacognitive learning strategies among Iranian EFL learners. International Journal of Language Learning and Applied Linguistics World, 7(1), 265-277.

Nickerson, R. S. (1994). The teaching of thinking and problem solving. In R. J. Sternberg (Ed.), Thinking and problem solving. San Diego: Academic. https://doi.org/10.1016/B978-0-08-057299-4.50019-0

Niemivirta, M. (1997). Gender differences in motivational-cognitive patterns of self-regulated learning. Paper presented at the Annual meeting of the American Educational Research Association, Chicago, IL.

O'Hare, L. O., \& McGuinness, C. (2009). Measuring critical thinking, intelligence, and academic performance in psychology undergraduates. The Irish Journal of Psychology, 30(3), 123-131. https://doi.org/10.1080/03033910.2009.10446304

Ocak, I., \& Kalender, M. D. (2017). Investigation of 6th grade students' critical thinking skills in terms of various variables (Kütahya Sample). Kastamonu Ĕgitim Dergisi, 25(4), 1587-1600. Retrieved from http://dergipark.gov.tr/kefdergi/issue/30766/332515

Oguz. A., \& Ataseven, N. (2016). The relationship between metacognitive skills and motivation of university students. Educational Process International Journal, 5(1), 54-64. https://doi.org/10.12973/edupij.2016.51.4

Osman, R. M., \& Githua, B. N. (2009). Analysis of students' critical thinking skills by location, gender and the skills relationship to motivation to learn academic disciplines in Amoud University, Somaliland. Journal of Technology and Education in Nigeria, 4(1/2), 1-10. https://doi.org/10.4314/joten.v14i1-2.54285

Özsoy, G., \& Günindi, Y. (2011). Prospective preschool teachers' metacognitive awareness. Elementary Education Online, 10(2), 430-440.

Özsoy, G., Çakıroğlu, A., Kuruyer, H. G., \& Özsoy, S. (2010). Sinıf öğretmeni adaylarının üstbilişsel farkındalık düzeylerinin bazı değisskenler bakımından incelenmesi. 9. Sınıf Öğretmenliği Eğitimi Sempozyumu (20-22 Mayls 2010). Elazı $\breve{g}, 489-492$.

Pascarella, E., \& Terenzini, P. (1991). How college affects students: Findings and insights from twenty years of research. San Francisco, CA: Jossey Bass.

Paul, R. (2004). The state of critical thinking today: The need for substantive concept of critical thinking, Retrieved from www.criticalthinking.org 
Pintrich, P. R., Smith, D. A. F, Garcia, T., \& McKeachie, W. J. (1993). Reliability and predictive validity of the motivated strategies for learning questionnaire (MSLQ). Educational and Psychological Measurement, 53, 801-803. https://doi.org/10.1177/0013164493053003024

Pithers, R. T., \& Soden, R. (2000). Critical thinking in education: A review. Educational Research, 42(3), 237-249. https://doi.org/10.1080/001318800440579

Renniger, K. A., Hidi, S., \& Krapp, A. (1992). The role of interest in learning and development. Hillsdael, NJ: Erlbaum.

Rozendaal, J. S., Minnaert, A., \& Boakerts, M. (2001). Motivation and self regulated learning in secondary vocational education: Information processing type and gender differences. Learning and Individual Differences, 13(4), 273-289. https://doi.org/10.1016/S1041-6080(03)00016-5

Sabna, E. P., \& Hameed, A. (2016). Metacognitive awareness for ensuring learning outcomes among higher secondary school students. IOSR Journal of Humanities and Social Science (IOSR-JHSS), 21(4), 101-106.

Sadeghi, B., Hassani, M. T., \& Rahmatkhah, M. (2014). The relationship between EFL learners' metacognitive strategies, and their critical thinking. Journal of Language Teaching and Research, 5(5), 1167-1175. https://doi.org/10.4304/jltr.5.5.1167-1175

Salahshoor, N., \& Rafiee, M. (2016). The relationship between critical thinking and gender: A case of Iranian EFL learners. Journal of Applied Linguistics and Language Research, 3(2), 117-123.

Schoen, D. (1983). The reflective practitioner. San Francisco: Jossey-Bass.

Schraw, G. (1998). Promoting general metacognitive awareness. Instructional Science, 26, 113-125. https://doi.org/10.1023/A:1003044231033

Schraw, G. (2001). Promoting general metacognitive awareness. In H. .J. Hartman (Ed.), Metacognition in learning and instruction. Boston: Kluwer Academic. https://doi.org/10.1007/978-94-017-2243-8_1

Schraw, G., \& Dennison, R. S. (1994). Assessing metacognitive awareness. Contemporary Educational Psychology, 19, 460-475. https://doi.org/10.1006/ceps.1994.1033

Schraw, G., \& Moshman, D. (1995). Metacognitive theories. Educational Psychological Review, 7, 351-371. https://doi.org/10.1007/BF02212307

Sczesny, S., \& Kühnen, U. (2004). Metacognition about biological sex and gender stereotypic physical appearance: Consequences for the assessment of leadership competence. Personality and Social Psychology Bulletin, 30(1), 13-21. https://doi.org/10.1177/0146167203258831

Semerci, Ç., \& Elaldı, Ş. (2014). The roles of metacognitive beliefs in developing critical thinking skills. Bartın University. Journal of Faculty of Education, 3(2), 317-333. https://doi.org/10.14686/BUEFAD.201428187

Sheorey, R., \& Mokhtari, K. (2001). Differences in the metacognitive awareness of reading strategies among native and non-native readers. System, 29, 431-449. https://doi.org/10.1016/S0346-251X(01)00039-2

Siswati, B. H., \& Corebima, A. D. (2017). The effect of education level and gender on students'metacognitive skills in Malang. Indonesia Advances in Social Sciences Research Journal, 4(4), 163-169.

Şen, Ü. (2009). An evaluation about Turkish teacher candidates' critical thinking attitudes in terms of different variables. Journal of World of Turks, 1(2), 69-89.

Thomas, T. (2011). Developing first year students' critical thinking skills. Asian Social Science, 7(4), 26-35. https://doi.org/10.5539/ass.v7n4p26

Vianty, M. (2007). The comparison of students' use of metacognitive strategies between reading in Bahasa Indonesia and in English. International Educational Journal, 8(2), 449-460.

Walberg, H. J., Harnisch, D. L., \& Tsai, S. (1986). Elementary school mathematics productivity in twelve countries. British Educational Research Journal, 12(3), 237-248. https://doi.org/10.1080/0141192860120302

Walsh, C. M., \& Hardy, R. C. (1999). Dispositional differences in critical thinking related to gender and academic major. Journal of Nursing Education, ProQuest Central, 38(4), 149-155.

Weil, L. G., Fleming, S. M., Dumontheil, I., Kilford, E. J., Weil, R. S., Rees, G., Dolan, R. J., \& Blakemore, S. J. (2013). The development of metacognitive ability in adolescence. Consciousness and Cognition, 22(1), 264-271. https://doi.org/10.1016/j.concog.2013.01.004 
Yang, S. C., \& Lin, W. C. (2004). The relationship among creative, critical thinking and thinking styles in Taiwan High school students. Journal of Instructional Psychology, 31(1), 33-45.

Zulkiply, N., Kabit, M. R., \& Ghani, K. A. (2008). Metacognition: What roles does it play in students' academic performance? The International Journal of Learning, 15, 97-105.

\section{Copyrights}

Copyright for this article is retained by the author, with first publication rights granted to the journal.

This is an open-access article distributed under the terms and conditions of the Creative Commons Attribution license (http://creativecommons.org/licenses/by/4.0/). 